\title{
Enteral Nutrition Support for Mechanically Ventilated, Morbidly Obese Patient with Abdominal Compartment Syndrome (ACS): A Case Report from a Medical Intensive Care Unit (ICU)
}

Received $30^{\text {th }}$ September 2017,

Accepted $29^{\text {th }}$ November 2017

Link to DOI:

10.25220/WNJ/V01.i2.0002

Journal Website:

www.worldnutrijournal.org

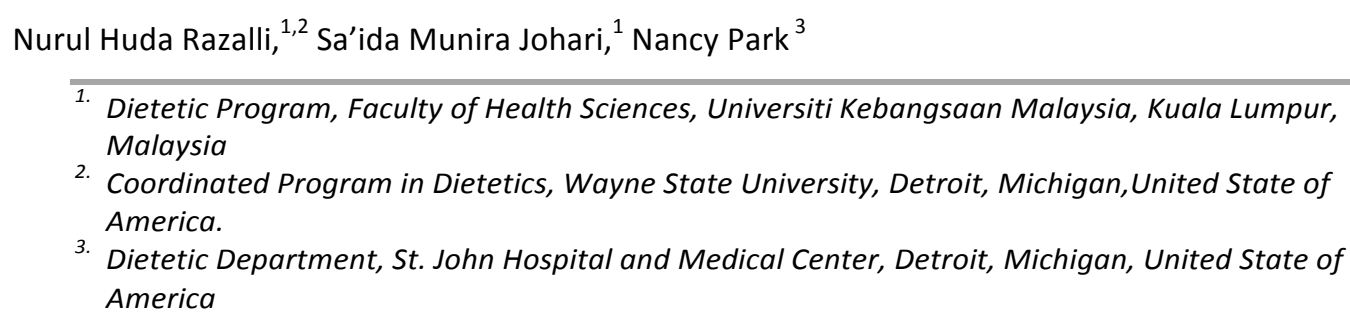

1. Dietetic Program, Faculty of Health Sciences, Universiti Kebangsaan Malaysia, Kuala Lumpur, Malaysia

2. Coordinated Program in Dietetics, Wayne State University, Detroit, Michigan, United State of America.

3. Dietetic Department, St. John Hospital and Medical Center, Detroit, Michigan, United State of America

\begin{abstract}
Abdominal compartment syndrome (ACS) is said to occur when intra-abdominal pressure (IAP) is greater than $20 \mathrm{mmHg}$ in association with new organ failure. This pressure can decrease blood flow to nerve and muscle cells, leading to ischemia and organ dysfunction. Challenges in providing enteral nutrition for abdominal compartment syndrome (ACS) patients include the increased risk for developing gastrointestinal symptoms such as diarrhea, constipation and distention. There are limited reports available on the nutritional management of ACS patients in the ICU, especially those with morbid obesity condition, to guide dietitians in providing nutritional support for these patients. Here, we report the enteral nutrition management of a mechanically ventilated, morbidly obese patient with ACS in a critical care setting by adopting post-pyloric feeding, using pro-kinetic agents and implementing $\mathrm{PO}_{2} / \mathrm{FiO}_{2}$ ratio calculation for prescription of most suitable enteral formula.
\end{abstract}

Keywords Critical Care Nutrition; Nutrition Support; Intensive Care Unit; Enteral Nutrition; Abdominal Compartment Syndrome

\section{Introduction}

Intra-abdominal hypertension (IAH) is defined by the World Society on Abdominal Compartment Syndrome (WSACS) as a persistent intraabdominal pressure greater than $12 \mathrm{mmHg}$. In

\footnotetext{
Corresponding author:

Nurul Huda Razalli, PhD, RD

Dietetic Program, Faculty of Health Sciences,

Universiti Kebangsaan Malaysia,

50300, Kuala Lumpur, Malaysia.

Phone number : : 6014-3772418

Email address : nurulhuda.razalli@ukm.edu.my
}

addition, abdominal compartment syndrome (ACS) is said to occur when intra-abdominal pressure (IAP) is greater than $20 \mathrm{mmHg}$ in association with new organ failure. ${ }^{1}$ The pressure can decrease blood flow to nerve and muscle cells, leading to ischemia and organ dysfunction. Studies have been suggested that the incidence of ACS and IAH, when associated with septic shock, can be as high as $30 \%$ to $85 \%$ respectively. ${ }^{2}$ Both ACS and IAH are growingly recognized complications impacting $30-50 \%$ of intensive care unit (ICU) patients and have mortality rates of $70-80 \%$ if left untreated. ${ }^{3-5}$

Some of the most common early clinical manifestations of IAH and ACS in critically ill 
patients including abdominal distention, oliguria, elevated peak respiratory pressures and difficulty in ventilating. Because of its simplicity and low cost, bladder pressure measurement has been considered as the gold standard to measure IAP. ${ }^{2,6-7}$

Studies have been shown that IAH can affect the central nervous system by raising intracranial pressure and also decreasing renal function. Malbrain et al. $^{3}$ reported that IAH could independently cause acute kidney injury (AKI). The effect of IAH on gastrointestinal organs leads to decreased gut perfusion. This change can lead to bowel ischemia and edema to infectious risk associated with mucosal hyperpermeability. ${ }^{8}$

The provision of nutrition care to the mechanically ventilated patients in the ICU, most commonly through enteral nutrition, is known to present with numerous challenges due to multidisciplinary and heterogeneous medical condition, severity of illness and specific individual needs. ${ }^{9}$ Furthermore, the presence of obesity in mechanically ventilated patients increases the complexity of care. The more severe the obesity, the more demanding the routine of nursing care and diagnostic or therapeutic interventions can be due to patients' physical condition. Similarly, providing enteral nutrition to the obese-mechanically ventilated patients can also be complicated as these patients are prone to develop stress-induced hyperglycemia. ${ }^{10}$ Obese-critically ill patients also have altered metabolic processes when compared to their non-obese counterpart. ${ }^{11-12}$

In terms of providing enteral nutrition for IAH/ACS patients, the challenges including the increase risk for developing gastrointestinal symptoms such as diarrhea, constipation and distention. The use of opiate sedation may contribute to decrease gastric motility. ${ }^{13}$ Additionally, in critically ill patients, there is an increased risk of developing serious metabolic complications due over feeding including hypercapnia, hyperglycemia, azotemia, hepatic steatosis and metabolic acidosis among others. ${ }^{14-15}$

There are limited reports available on the nutritional management of ACS patients in the ICU especially those with morbid obesity condition to guide dietitians in providing nutritional support for these patients. Here, we report the enteral nutrition management of a mechanically ventilated, morbidly obese patient with ACS in a critical care setting by adopting post-pyloric feeding, using prokinetic agents and implementing $\mathrm{PO}_{2} / \mathrm{FiO}_{2}$ ratio calculation for prescription of most suitable enteral formula.

\section{Client History}

A 53-year-old African American female with severe chronic obstructive pulmonary disease (COPD) presented to the Emergency Department with progressive symptoms of severe shortness of breath and swelling of lower extremities. She had a known past medical history of severe oxygen dependent COPD. In the last 12 months, she had multiple hospitalizations for COPD exacerbations.

Upon presentation, she was afebrile with elevated white blood cell count. Chest x-ray showed bilateral atelectasis while her ECG revealed sinus tachycardia with no acute ischemic changes. She was then admitted with initial diagnosis of acute respiratory failure and subsequently transferred to the medical intensive care unit (MICU) for ventilator support. In MICU, she was intubated, sedated and received fluid resuscitation. During the next 24 hours, she had periods of low urine output and subsequently developed non-oliguric acute kidney injury (AKI) with worsening metabolic acidosis. Noticeable increase in bladder pressure and abdominal distension revealed a diagnosis of abdominal compartment syndrome. In the meantime, progressive hypercapnea and auto-PEEP had led to the decision to chemically paralyze her with the neuromuscular blocking agent (NMBA), cisatracurium. She was then maintained on a continuous infusion of cisatracurium. Shortly following paralysis, bladder pressure decreased and she had urine output of more than $300 \mathrm{ml}$. During the next few days, her creatinine level returned to normal. She continued to receive other non-surgical therapy to control IAP by gastric decompression and soapsuds enema.

The patient was kept nothing by mouth (NPO), following sedation and intubation in the ICU. Bedside placement of a naso-jejunal feeding tube was done within 72 hours after admission using electromagnetically guided placement device 
(EMPD) and dietitian was consulted on Day 3 for enteral nutrition initiation.

\section{Nutrition Care Process:}

\section{Nutrition Assessment}

Patient was morbidly obese (BMI of $40.6 \mathrm{~kg} / \mathrm{m}^{2}$ ) with admission weight of $100.8 \mathrm{~kg}$. Her ideal body weight (IBW) for her height of $157.5 \mathrm{~cm}$ was 50 $\mathrm{kg}$. She was at $202 \%$ of her IBW and $110 \%$ of her usual body weight (UBW) during presentation at the hospital with no reported weight loss prior to admission. This was supported by her last documented weight available on hospital electronic record $(91 \mathrm{~kg})$ indicating $10 \%$ weight gain in 10 months.

Information on food/nutrition-related history was obtained mainly from the nutrition screening form upon admission and the medical record. Prior to admission, the patient was not reported to follow a weight loss diet or any other therapeutic diet for her morbid obesity condition and other nutrition-related clinical diagnoses. The patient was kept NPO following sedation and intubation in the ICU.

Biochemical assessment revealed elevated levels of blood urea nitrogen (BUN), serum creatinine and phosphorus related to AKI resulted from ACS. Other electrolytes and $\mathrm{CO}_{2}$ level were within normal limits (Table 1). In order to determine the patient's lung function, partial pressure of oxygen/fraction of inspired oxygen $\left(\mathrm{PO}_{2} / \mathrm{FiO}_{2}\right)$ ratio was calculated $\left(\mathrm{PO}_{2}, 93.6 \mathrm{mmHg}\right.$; $\mathrm{FiO}_{2}, 40 \%$ from arterial blood gas analysis and ventilator setting respectively). Calculation of $\mathrm{PO}_{2} / \mathrm{FiO}_{2}$ ratio $(<300 \mathrm{mmHg})$ revealed a status of acute lung injury (ALI).

Table 1 Biochemical data

\begin{tabular}{lcccccc}
\hline Parameter & Reference range & Day 3 & Day 6 & Day 10 & Day 20 & Day 23 \\
\hline Sodium (mmol/L) & $135-145$ & 137 & 152 & 138 & 141 & 139 \\
Potassium (mmol/L) & $3.5-5.2$ & 5.2 & 5.6 & 5.1 & 4.6 & 3.7 \\
Chloride (mmol/L) & $98-109$ & 98 & 108 & 95 & 104 & 100 \\
Carbon dioxide, CO $\mathrm{CO}_{2}(\mathrm{mmol} / \mathrm{L})$ & $23-34$ & 27 & 37 & 39 & 29 & 30 \\
Blood urea nitrogen (mg/dL) & $8-20$ & 40 & 41 & 32 & $\mathrm{NA}$ & 14 \\
Creatinine (mg/dL) & $0.70-1.20$ & 3.31 & 0.85 & 0.54 & 0.31 & 0.29 \\
Magnesium (mEq/L) & $1.3-1.9$ & $\mathrm{NA}$ & 2.1 & 2.4 & 3.0 & 1.5 \\
Phosphorus (mg/dL) & $2.4-4.5$ & 6.8 & 2.8 & 3.2 & 2.3 & NA \\
Albumin $(\mathrm{g} / \mathrm{dL})$ & $3.5-5.0$ & 3.6 & 3.3 & 3.5 & $\mathrm{NA}$ & NA \\
White blood cell & $4.0-11.0$ & 17.8 & 13.8 & 20.7 & 11.9 & 6.7 \\
(Thou/cu mm) & & & & & & \\
Glucose (mg/dL) & $70-200$ & 148 & 224 & 149 & 122 & 133 \\
\hline
\end{tabular}

$\mathrm{NA}=$ Not Available

Energy needs were initially estimated based on Penn $2003 b^{16}$ formula at $1681 \mathrm{kcal}$ per day using admission weight. Protein needs were calculated at
$110 \mathrm{~g}$ per day $(2.0 \mathrm{~g} / \mathrm{kg}$ IBW/day) based on ASPEN recommendation for critically ill adults with BMI between $30-40 \mathrm{~kg} / \mathrm{m}^{2}{ }^{17}$ Fluid needs were not specified and were based on physician order due to 
the critical condition of patient requiring fluid resuscitation.

\section{Nutrition Diagnosis}

Patient had increased energy and protein needs from her critical illness. However, enteral nutrition support was not initiated within 24-48 hours due to hemodynamic instability. Patient was at risk of malnutrition in acute setting with delayed initiation of feeding. The nutrition diagnosis during initial assessment was "Inadequate protein and energy intake related to medical condition, intubation and altered gastrointestinal function as evidenced by patient on ventilator, estimated nutrient needs not met, current NPO status and unable to initiate feedings to rule out ileus".

\section{Nutrition Intervention and Prescription}

Nasojejunal feeding of Oxepa ${ }^{\circledR},{ }^{18}$ a concentrated enteral formulation with anti-inflammatory lipid profile and antioxidants was recommended to be initiated at $20 \mathrm{~mL} /$ hour continuously over 24 hours with slow feeding rate advancement as tolerated by the patient to the goal rate of $40 \mathrm{~mL} /$ hour. Healthy Shot $^{\circledR}$, a liquid high protein supplement was also recommended to be given twice daily via feeding tube in order to meet the patient's high protein needs providing in total of $1640 \mathrm{kcal}$ and $108 \mathrm{~g}$ protein per day. The use of additional modular protein supplements to ensure adequate delivery of protein is a common practice. ${ }^{18}$ In addition, Healthy Shot ${ }^{\mathbb{B}}$ was the only liquid modular protein supplement available at the facility for enteral feeding use, thus, it was chosen to be given to patient in order to meet her high protein needs (Table 2).

\section{Nutrition Monitoring/Evaluation and Outcome}

Parameters monitored for this patient included electrolyte profile, enteral nutrition tolerance, enteral nutrition intake, gastrointestinal profile, glucose/endocrine profile, renal profile, protein profile and $\mathrm{CO}_{2}$ levels (Table 1). Upon follow up, elevated $\mathrm{CO}_{2}$ and glucose levels were seen (Day 6) indicating possible overfeeding. Permissive hypocaloric feeding was then introduced, revising the energy requirement at 1109-1411 kcal (11-14 $\mathrm{kcal} / \mathrm{kg}$ actual body weight per day) based on obese, critically ill adults guidelines ${ }^{18}$ while maintaining the same high protein needs. Permissive hypocaloric feeding is defined as intentional delivery of less non-protein nutrients than what is normally required daily. The concept of permissive hypocaloric feeding is based on the rationale that higher nutrient intake is detrimental from a metabolic and functional perspective. Studies with obese patients have demonstrated that a hypocaloric feeding regimen can promote nitrogen equilibrium and minize negative nitrogen balance without causing weight loss. ${ }^{19}$

The goal rate for Oxepa ${ }^{\circledR}$ was modified to $35 \mathrm{~mL} / \mathrm{hr}$ with Healthy Shot ${ }^{\circledR}$ order of twice daily remained as previously prescribed. To optimize bowel management, pro-motility agents, Reglan and erythromycin were also recommended. On Day 21, patient was transferred to ICU step down unit and was discharged on Day 32 to a long term acute care facility with a feeding tube regimen using Glucerna $1.2^{\circledR}$, a calorically dense diabetes-specific formula planned for better carbohydrate intake control in view of the patient having a chronic COPD. Energy needs for discharge plan was calculated using the Mifflin-St. Jeor formula (x1.2 factor) with protein needs of $2.0 \mathrm{~g} / \mathrm{kg}$ IBW per day (1850 kcal, $100 \mathrm{~g}$ protein per day). The formula is commonly used in clinical practice and it is the most reliable, predicting Resting Metabolic Rate (RMR) within $10 \%$ of measured in non-obese and obese individuals than any other equation and it also had the narrowest error range. ${ }^{20}$ The recommended goal rate was $65 \mathrm{~mL} / \mathrm{hr}$ providing $1880 \mathrm{kcal}, 94 \mathrm{~g}$ protein and $179 \mathrm{~g}$ carbohydrate. Table 3 summarizes enteral nutrition prescriptions for this patient throughout her hospitalization. 
Table 2 Nutrition facts for nutrition intervention prescriptions

\begin{tabular}{|c|c|c|c|}
\hline Nutrition facts & Oxepa $^{B}(1000 \mathrm{~mL})$ & $\begin{array}{c}\text { Healthy Shot }^{\circledR} \\
(75 \mathrm{~mL})\end{array}$ & $\begin{array}{c}\text { Glucerna } 1.2^{\circledR} \\
(237 \mathrm{~mL})\end{array}$ \\
\hline Calories (kcal) & 1500 & 100 & 285 \\
\hline Protein $(\mathrm{g})$ & 62.7 & 24 & 14.2 \\
\hline Total carbohydrate $(\mathrm{g})$ & 105.3 & 1 & 27.1 \\
\hline Total fat $(\mathrm{g})$ & 22.2 & 0 & 14.2 \\
\hline Water $(\mathrm{mL})$ & 186 & NA & 192 \\
\hline Vitamin A (IU) & 2840 & NA & 1840 \\
\hline Beta-carotene (mg) & 1.2 & NA & 0.63 \\
\hline Vitamin D (IU) & 100 & NA & 82 \\
\hline Vitamin E (IU) & 75 & NA & 9.2 \\
\hline Vitamin K (mcg) & 20 & NA & 24 \\
\hline Vitamin C (mg) & 205 & 22.5 & 62 \\
\hline Folic acid (mcg) & 200 & NA & 76 \\
\hline Thiamin (mg) & 0.75 & NA & 0.29 \\
\hline Riboflavin (mg) & 0.85 & NA & 0.33 \\
\hline Vitamin B6 (mg) & 1.0 & NA & 0.38 \\
\hline Vitamin B12 (mcg) & 3.0 & NA & 1.2 \\
\hline Niacin $(\mathrm{mg})$ & 10 & NA & 3.8 \\
\hline Choline (mg) & 150 & NA & 105 \\
\hline Biotin (mcg) & 150 & NA & 57 \\
\hline Panthothenic acid (mg) & 5.0 & NA & 1.9 \\
\hline Sodium (mg) & 310 & 80 & 265 \\
\hline Potassium (mg) & 465 & NA & 480 \\
\hline Chloride (mg) & 400 & $\mathrm{NA}$ & 305 \\
\hline Calcium (mg) & 250 & 78 & 190 \\
\hline Phosphorus (mg) & 250 & NA & 190 \\
\hline Magnesium (mg) & 100 & NA & 76 \\
\hline Iodine $(\mathrm{mcg})$ & 38 & NA & 29 \\
\hline Manganese (mg) & 1.3 & NA & 0.38 \\
\hline Copper (mg) & 0.50 & NA & 0.38 \\
\hline Zinc (mg) & 5.7 & NA & 2.9 \\
\hline Iron (mg) & 4.5 & 0.7 & 3.5 \\
\hline Selenium (mcg) & 18 & NA & 14 \\
\hline Chromium (mcg) & 30 & NA & 38 \\
\hline Molybdenum (mcg) & 38 & NA & 19 \\
\hline L-carnitine (mg) & 43 & NA & NA \\
\hline Taurine (mg) & 75 & NA & NA \\
\hline
\end{tabular}

$\mathrm{NA}=$ Not Available 
Table 3 Enteral nutrition prescriptions

\begin{tabular}{|c|c|c|c|c|c|}
\hline \multirow{2}{*}{$\begin{array}{l}\text { Hospitalization } \\
\text { Day } \\
\end{array}$} & \multirow{2}{*}{$\begin{array}{c}\text { Energy Needs } \\
\text { (kcal/day) }\end{array}$} & \multirow{2}{*}{$\begin{array}{c}\text { Protein Needs } \\
\text { (g/day) }\end{array}$} & \multicolumn{3}{|c|}{ Enteral Formula Prescription } \\
\hline & & & Oxepa $^{(B)}$ & Healthy Shot $^{(\mathbb{R}}$ & Glucerna $1.2^{\circledR}$ \\
\hline $\begin{array}{l}\text { Day } 1 \\
\text { (MICU admission) }\end{array}$ & \multicolumn{5}{|c|}{ Feeding not yet initiated } \\
\hline \multirow[t]{2}{*}{$\begin{array}{l}\text { Day } 3 \\
\text { (Initial RD } \\
\text { consultation) }\end{array}$} & $\begin{array}{c}1681 \\
(\text { Penn 2003b })^{16}\end{array}$ & 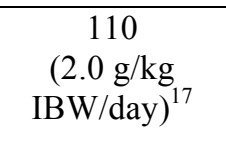 & $\begin{array}{l}\text { Start rate: } 20 \\
\text { mL/hour } \\
\text { Goal rate: } 40 \\
\text { mL/hour }\end{array}$ & $75 \mathrm{~mL}$ bd & - \\
\hline & & \multicolumn{4}{|c|}{$\begin{array}{c}\text { Energy: } 1460 \mathrm{kcal} / \text { day } \\
\text { Protein: } 101 \mathrm{~g} / \text { day }\end{array}$} \\
\hline \multirow[t]{2}{*}{$\begin{array}{l}\text { Day } 6 \\
\text { (Day } 5 \text { post EN } \\
\text { initiation) } \\
\end{array}$} & $\begin{array}{c}1109-1411 \\
(11-14 \mathrm{kcal} / \mathrm{kg} \\
\text { ABW per day })^{17}\end{array}$ & $\begin{array}{c}110 \\
(2.0 \mathrm{~g} / \mathrm{kg} \\
\text { IBW/day })^{17}\end{array}$ & $35 \mathrm{~mL} /$ hour & $75 \mathrm{~mL} \mathrm{bd}$ & - \\
\hline & & \multicolumn{4}{|c|}{$\begin{array}{l}\text { Energy: } 1460 \mathrm{kcal} / \text { day } \\
\text { Protein: } 101 \mathrm{~g} / \text { day }\end{array}$} \\
\hline \multirow[t]{2}{*}{$\begin{array}{l}\text { Day } 21 \\
\text { (Transferred to } \\
\text { ICU step down } \\
\text { unit) }\end{array}$} & $\begin{array}{c}1109-1411 \\
(11-14 \mathrm{kcal} / \mathrm{kg} \\
\text { ABW per day })^{17}\end{array}$ & $\begin{array}{c}110 \\
(2.0 \mathrm{~g} / \mathrm{kg} \\
\text { IBW/day })^{17}\end{array}$ & $35 \mathrm{~mL} / \mathrm{hour}$ & $75 \mathrm{~mL} \mathrm{bd}$ & - \\
\hline & & \multicolumn{4}{|c|}{$\begin{array}{c}\text { Energy: } 1460 \mathrm{kcal} / \text { day } \\
\text { Protein: } 101 \mathrm{~g} / \text { day }\end{array}$} \\
\hline \multirow[t]{2}{*}{$\begin{array}{l}\text { Day } 32 \\
\text { (Discharged plan) }\end{array}$} & $\begin{array}{c}1850 \\
\text { (Mifflin St. } \\
\text { Jeor) } \\
\end{array}$ & $\begin{array}{c}100 \\
(2.0 \mathrm{~g} / \mathrm{kg} \\
\text { IBW/day })^{17}\end{array}$ & - & - & $65 \mathrm{~mL} / \mathrm{hour}$ \\
\hline & & & & & $\begin{array}{c}\text { Energy: } 1880 \\
\text { kcal/day } \\
\text { Protein: } 94 \\
\text { g/day }\end{array}$ \\
\hline $\begin{array}{l}\text { MICU = Medical In } \\
\text { RD = Registered Di }\end{array}$ & $\begin{array}{l}\text { nsive Care Unit } \\
\text { itian }\end{array}$ & & $\begin{array}{l}\mathrm{bd}=\text { twice } \mathrm{a} \\
\mathrm{EN}=\text { Entera }\end{array}$ & trition & \\
\hline
\end{tabular}

\section{Discussion}

ACS commonly occurs in critically ill patients. Among other gastrointestinal effects from this syndrome, gut hypo-perfusion that may lead to bowel ischemia together with decreased gastric motility as part of IAH pathophysiology and the impact from opiate sedation are of major concerns in providing a successful enteral feeding. In this report, there were three major nutrition concerns. Firstly, in a patient with IAH, enteral feeding itself can aggravate bowel ischemia or worsen IAH due to fermentation and bowel distention and gastrointestinal symptoms. ${ }^{21}$ Secondly, possibility of feeding intolerance secondary to decreased gastric motility from opiate sedation. ${ }^{13}$ Thirdly, increased risk of developing serious metabolic complications if over feeding occurs. ${ }^{14,15}$

Overall, our patient was able to tolerate the hypocaloric, high protein enteral feeding regimen despite several feeding interruptions due to medical condition and procedures.

In conclusion, provision of enteral nutrition support for ACS patients requires careful attention and aggressive measures such as adopting postpyloric feeding to maximize the delivery of enteral feeding. Hill et al. ${ }^{8}$ previously reported a low percentage of possibility for exclusive enteral nutrition support via nasogastric among these patients, thus, post-pyloric feeding should be considered. It is also beneficial to use pro-kinetic agents to optimize bowel management in managing ACS cases. Furthermore, in mechanically ventilated patients, $\mathrm{PO}_{2} / \mathrm{FiO}_{2}$ ratio calculation is useful for possible prescription of formula suitable for lung impairment. 


\section{Conflict of Interest}

The authors of this paper declare there is no conflict of interest regarding this research.

\section{Open Access}

This article is distributed under the terms of the Creative Commons Attribution 4.0 International License (http://creativecommons.org/licenses/by/4.0/), which permits unrestricted use, distribution, and reproduction in any medium, provided you give appropriate credit to the original author(s) and the source, provide a link to the Creative Commons license, and indicate if changes were made.

\section{References}

1. Malbrain ML, Cheatham ML, Kirkpatrick A, Sugrue M, Parr M, Waele, J. De , et al. Results from the international conference experts on intra-abdominal hypertension and abdominal compartment syndrome. I. Definitions. Intensive Care Med 2006;32:1722-32. [Google Scholar]

2. Daugherty EL, Liang $H$, Taichman D, Hansen-Flaschen J, Fuchs BD. Abdominal compartment syndrome is common in medical intensive care unit patients receiving large-volume resuscitation. J Intensive Care Med 2007;22:294-9. [Google Scholar]

3. Malbrain ML, Chiumello D, Pelosi P, Bihari D, Innes $\mathrm{R}$, et al. Incidence and prognosis of intraabdominal hypertension in a mixed population of critically ill patients: a multiple-center epidemiology study. Crit Care Med 2005;33:315-322. [Google Scholar]

4. Sugrue M. Abdominal compartment syndrome. Curr Opin Crit Care 2005;11:333-8. [Google Scholar]

5. Theodossis SP, Athanasios DM, Ioannis $\mathrm{P}$, Isaak K, Nicki P. Abdominal compartment syndrome-Intraabdominal hypertension: Defining, diagnosing, and managing. $\mathrm{J}$
Emerg Trauma Shock 2011;4(2):279-91. [Google Scholar]

6. Cheatham ML, Malbrain ML, Kirkpatrick A, Surgue M, Parr M, Waele, J. De , et al. Results from the International Conference Experts on Intra-abdominal Hypertension and Abdominal Compartment Syndrome. II. Recommendations. Intensive Care Med 2007;33:951-62. [Google Scholar]

7. Malbrain M. Different techniques to measure intra-abdominal pressure (IAP): Time for a critical appraisal. Intensive Care Med 2004;30:357-71. [Google Scholar]

8. Hill LT, Miller M. The effect of intraabdominal hypertension on gastrointestinal function. Southern African Journal of Critical Care 2011;27(1):12-8. [Google Scholar]

9. Yip KF, Rai V, Wong KK. Evaluation of delivery of enteral nutrition in mechanically ventilated Malaysian ICU patients. BMC anesthesiology 2014;14(1):127. [Google Scholar]

10. Port AM, Apovian C. Metabolic support of the obese intensive care unit patient: a current perspective. Curr Opin Clin Nutr Metab Care 2010;13(2):184-191. [Google Scholar]

11. Secombe P, Harley S, Chapman M, Aromataris E. Feeding the critically ill obese patient: a systematic review protocol. JBI Database System Rev Implement Rep 2015;13(10):95-109. [Google Scholar]

12. Jeevanadam M, Young DH, Schiller WR. Obesity and the metabolic response to severe multiple trauma in man. J Clin Invest 1991;87(1):262-269. [Google Scholar]

13. Nguyen NQ, Chapman MJ, Frase RJ, Bryant LK, Burgstad C, Ching K, et al. The effects of sedation on gastric emptying and intra-gastric meal distribution in critical illness. Intensive Care Med 2008;34:454460. [Google Scholar]

14. Reid C. Frequency of under- and overfeeding in mechanically ventilated ICU patients: causes and possible consequences. J Hum Nutr Dietet 2006;19:13-22. [Google Scholar] 
15. Klein CJ, Stanek GS, 3rd WCE. Overfeeding macronutrients to critically ill adults: metabolic complications. J Am Diet Assoc 1998;98(7):795-806. [Google Scholar]

16. Frankenfield D, Smith JS, Cooney RN. Validation of 2 approaches to predicting resting metabolic rate in critically ill patients. JPEN 2004;28:259-264. [Google Scholar]

17. McClave SA, Taylor BE, Martindale RG, Warren MM, Johnson DR, Braunschweig $\mathrm{C}$, et al. Guidelines for the provision and assessment of nutrition support therapy in the adult critically ill patient: Society of Critical Care Medicine (SCCM) and American Society for Parenteral and Enteral Nutrition (A.S.P.E.N. JPEN 2016;40(2):159-211. [Google Scholar]

18. McClave SA, Martindale RG, Vanek VW, McCarthy M, Roberts P, Taylor B, et al. Guidelines for the provision and assessment of nutrition support therapy in the adult critically ill patient: Society of critical care medicine (SCCM) and American Society for Parenteral and Enteral Nutrition (A.S.P.E.N. JPEN J Parenteral Enteral Nutr 2009;33(3):277-316. [Google Scholar]

19. Malone AM. Permissive underfeeding: its appropriateness in patients with obesity, patients on parenteral nutrition, and nonobese patients receiving enteral nutrition. Curr Gastroenterol Rep 2007;9(4):317-322. [Google Scholar]

20. Frankenfield D, Roth-Yousey L, Compher C. Comparison of predictive equations for resting metablic rate in healthy nonobese and obese adults: a systematic review. J Am Diet Assoc 2005;105(5):775-789. [Google Scholar]

21. Hill LT, Hill B, Miller M, Michell WL. The effect of intra-abdominal hypertension on gastro-intestinal fucntion. Southern African J Crit Care 2011;27(1):12-19. [Google Scholar] 